Оригинални научни рад УДК 821.163.41.09-4 Анрић И. 821.112.2.09-32 Ман Т. Примљен: 31. марта 2021. Прихваћен: 6. маја 2021. Сара 3. Арва ${ }^{1}$

Универзитет у Београду

Филолошки факултет

Српска књижевност са јужнословенским књижевностима

\title{
УМЕТНОСТ - ЗЛОЧИН ИЛИ БОЛЕСТ: ГОЈА И КРЕГЕР У КОМПАРАТИВНОМ ТУМАЧЕЊУ
}

\begin{abstract}
У раду ће бити тумачена фигура уметника у Андрићевим (1892-1975) есејима „Разговор са Гојом“ и „Гоја“ и Мановој (Thomas Mann, 1875-1955) новели „Тонио Крегер“ (Tonio Kröger, 1903). Компаративна анализа биће утемељена на Ничеовим (Nietzsche) филозофским становиштима, а књижевни јунак уметник сагледан као маргинализовани појединац који не успева да се уклопи у друштвене околности свога времена. Нестални идентитет и неутемељена друштвена позиција уметника омогућавају двоструки аспект тумачења - уметник може бити разматран као злочинац, индивидуа која чини преступ не би ли стварала; али и индивидуа са патолошким тенденцијама, која свој душевни немир испољава стваралачким напорима. У оба случаја, исход је исти - књижевни јунаци стварају и настаје уметност као једини облик егзистенције. Ипак, за Гоју и Крегера уметност је амбивалентног усмерења: она је истовремено и сужањство и слобода, и склад и деструкција - што ће такође бити додатно проблематизовано у овом истраживању.
\end{abstract}

Кључне речи: Андрић, Ман, Ниче, уметник, уметност, друштво, злочин, болест

\section{1. Увод}

Многе савремене студије начиниле су значајан осврт на фигуру уметника и тумачиле његов положај у књижевним делима. У монографији Парадоксални класик Томас Ман, Драган Стојановић примећује да Ман насловног јунака новеле „Тонио Крегер“ замишља као „изопштеника из грађанске сфере“, који стваралаштвом одговара на неузвраћену грађанску љубав (STOJANOVIĆ 1997: 16-17). Истраживач истовремено указује и на душевно стање књижевног јунака, промене које се одвијају у оквиру мисаоне артикулације уметника, али и на сукоб аполонског и

1 sara.arva@gmail.com 
диониског принципа као директну последицу Манове упућености у Ничеову филозофију (STOJANOVIĆ 1997: 19-26). Бројни су и радови које је Аница Савић Ребац посветила проучавању Манове духовне делатности, а онај који се дотиче нашег интересовања, под насловом „Томас Ман и проблем уметника“, сагледа три ступња Мановог уметничког рефлекса и различито обликованог израза у зависности од жанра за који се аутор определио - романа, новеле или расправе (SAVIĆ REBAC 2015: 451). Разматрајући новеле, Аница Савић Ребац закључује да је инспирација за стварање „уметник у животу, а позиција Манова [je] на болној размеђи живота и стварања, човештва и уметништва“ (SAVIĆ REBAC 2015: 451). Приметно је одсуство дистинцкије аутор - дело, будући да Аница Савић Ребац књижевног јунака сагледа као израз пишчеве „најинтимније душевне садржине“, наглашавајући притом и „већу интимност и сродничку блискост творца и творевине“, као и чињеницу да је Ман својим јунацима „дао крв своје крви“ (SAVIĆ REBAC 2015: 452-457).

У савременој научној полемици не недостаје ни студија које у фокус смештају Андрићевог уметника - сликара Гоју - па тако Анка Симић (SIMIĆ 2017:61-68) у раду „Андрићева легенда о уметнику: Разговор с Гојом“ проблематизује статус уметника као књижевног јунака (Гоје), али и аутора (Андрића) који иманентно проговара о дискурсу стваралачког импулса. Ауторка непрестано доводи у везу Гојине исказе са Андрићевим поетичким усмерењима, те књижевним делом потврђује пишчеву мисао о уметности (SIMIĆ 2017: 66). На сличним полазиштима своје истраживање темељи и Миљан Ђурчинов у раду „Маскирани човек у сумраку (О неким компонентама Андрићеве поетике)“. Детаљно анализирајући есеј „Разговор са Гојом“, Ђурчинов успоставља аналогије између одлика Андрићеве списатељске активности и њених рефлексија испољених управо у имагинарном дијалогу са Гојом, закључујући да је књижевни јунак пишчев алтер-его (ĐURČINOV 1981: 104). Да су везе двају уметника - Андрића и Гоје, приповедача и сликара - биле повод за мисао о уметности, закључује и Тартаља још у прошлом веку: „На снажним акордима мадридских реминисценција инспирисана је овде једна естетичка балада у којој се уметничка искуства шпанског сликара и југословенског приповедача сливају у пророчки говор о судбини и позвању уметника, и шире, о човековом месту у друштву и космосу“ (TARTALJA 1979: 53).

Настојећи да се удаљимо од приступа пређашњих истраживања и тумачимо јунаке као иманентне панданде аутора који су их и створили, у средиште анализе ћемо сместити искључиво књижевне ликове - уметнике који припадају свету књижевног дела - и пратити њихове стваралачке тенденције. Међутим, остаћемо на трагу већ утврђених Стојановићевих теза о расколу уметника са друштвом које га окружује, те његове 
потребе да ствара не би ли тиме омогућио егзистенцију сопственог израза. Ипак, направићемо искорак од аполонско-диониске амбиваленције уметничког (само)сазнања, коју је Ниче изнео у Рођеюу трагедије (Die Geburt der Tragödie aus dem Geist der Musik, 1872), и пратити његову позну филозофију, обликовану у Сутону идола (Götzen-Dämmerung oder Wie man mit dem Hammer philosophirt, 1889) и Вољи за моћ (der Wille zur Macht, 1901), уочавајући је на примерима Мановог и Андрићевог књижевног јунака - уметника.

\section{2. Маскирани човек у сумраку - мимикрија, уметник и злочин}

Фигура уметника у књижевним делима двадесетог века не заузима привилеговану позицију. Гашењем идеја о апсолуту, превазиђене су могућности античких тумачења - када је уметник био посредник између божанског и земаљског. Услед тога, уметник се нашао у медијалној позицији у којој су и једна и друга могућност неоствариве - удаљио се од божанског света, али се није уклопио ни у земаљски. Модернизам је допринео расколу уметника и друштва, а он је приметан и у Андрићевом и у Мановом књижевном остварењу. Оба аутора портретишу лик уметника посредством његове нестабилне позиције у друштву. Такав однос се различито пројектује на књижевне уметнике - Гоју и Крегера - али спојна тачка остаје у њиховом дефинисању као отуђених и изолованих припадника, заправо - неприпадника грађанског и свакодневног. Маргинализована позиција приближава их ономе што би се могло дефинисати као злочиначки модус. Ниче је своја филозофска становишта о типу злочинца изнео у Сутону идола, образложивши својства злочиначке природе (NIČE 2017: 105). Наиме, према Ничеу, овом модусу припадају особе лишене разумевања друштва (2017: 105). Немачки филозоф истиче да су оне „прожете свешћу да нису једнаке с другима него одбачене, недостојне“ (2017: 105). Међутим, он сматра и да су сви облици егзистенције којима данас прилазимо с поштовањем заправо живели у тој „полугробничкој атмосфери“ људског неразумевања - између осталог, поред слободног духа, лекара, генија (2017: 105); Ниче у ову групу експлицитно сврстава и уметника (2017: 105). Фигура уметника се у Ничеовој филозофској мисли утемељује управо кроз злочиначки модус: „Све што живи по страни, све што је дуго, сувише дуго било на дну, сваки непроницљиви и инокосни облик егзистенције, примиче [се] типу који артикулише злочинац“ (2017: 105). Отуд закључујемо да је позиција уметника скрајнута од уобичајених друштвених токова. Уметник је одбачен, неприхваћен, а најтежи исход овакве деградираности јесте његова свест о немогућности да се уклопи у тривијално које га окружује, а којем неретко жели да припада.

2 Гоја овако дефинише уметника (ANDRIĆ 2011a: 25). 
Ослањајући се на Ничеове поставке о злочиначком модусу који је инхерентан уметницима, неопходно је подробно сагледати како се у Андрићевом и Мановом јунаку развијају овакве могућности. Док Гоја говори о „јазу између уметника и друштва“ (ANDRIĆ 2011a: 25), Ниче се служи лексиком за коју се, према преводу, ${ }^{3}$ чини да је истог значења, не би ли указао на друштвену одељеност уметника и то да су „сви иноватори духа [...] сами осећали стравичан јаз који их је делио од свега традиционалног и поштованог“ (2017: 105-106). Кључни моменат смо претходно навели - уметници су сами осећали тај јаз (2017: 105) - он јесте друштвено условљен, али је додатно наглашен у свести књижевног јунака, што поспешује његов деструктивни импулс. Зато Гоја проговара о нестабилном идентитету уметника:

„Видите, уметник то је 'сумњиво лице', маскиран човек у сумраку, путник са лажним пасошем. Лице под маском је дивно, његов ранг је много виши него што у пасошу пише, али шта то мари? Људи не воле ту неизвесност и закукуљьеност, и зато га зову сумюивим и дволичним. [...] Све и кад би уметник могао некако да објави свету своју праву личност и своје позвање, ко би му веровао да је то његова последња реч? И кад би показао свој прави пасош, ко би веровао да нема у џепу сакривен неки трећи?“ (2011а: 25).

Неопходно је уочити мотив мимикрије на који књижевни јунак алудира. Он је у уској вези са оним што Гоја нарочито покушава да дискредитује током разговора - позоришном уметношћу (2011a: 29-30). 3а Гоју, глумачки позив је „најтежи и најбеднији од свих позива“, док је у позориштима све „прашно и нечисто“ (2011а: 29). Међутим, и позориште је једна од грана на дрвету уметности - те је, иако сагледано с негативног аспекта, сродни елемент било ком уметничком позиву. Управо је сложена способност прерушавања и маскирања особена глумцима, а истовремено је суштинска за књижевног јунака, уметника - он без маске у свету тешко да може опстати. Иако Гоја глорификује лице уметника под маском и назива га дивним (2011a: 25), Манов јунак има нешто другачије становиште. У оквиру разговора са Лизаветом Ивановном, сликарка у једном тренутку подсмешљиво коментарише његову одору, на шта јој поета одсечно одговара: „Кад је човек уметник, довољно је у души пустолов. Споља се треба добро обући, и понашати се као пристојан човек...“ (MAN 2001: 34). Прерушавајући се у „пристојног човека“ (2001: 34), сакривајући своју уметничку бит и, сходно употребљеној синтагми, непристојни идентитет, Тонио Крегер покушава да се свету представи као обичан грађанин, што и јесте оно чему, како смо већ утврдили, његов људски део неизмерно тежи. Чак и у тренутку када се врати у своју домо3 Према преводу Јовице Аћина. 
вину више од деценију касније, Крегер стоји пред огледалом, посматра свој лик и „одједном се осети поузданијим иза своје маске, иза тог лица тако рано избразданог радом, које беше старије од њега самог“ (2001: 52). Црте старости и изглед који наличи човеку јесу његов костим пред људима, маска која му омогућава непрепознатљивост и избегавање могућих нелагодности. Иако уметник носи себи својстен жиг, он мимикријски настоји да га прикрије ликом обичног човека - мада он то не може бити.

Међутим, Гојин исказ о „маскираном човеку у сумраку“ (2011а: 25) дефиниција је која не одговара само уметницима или пак глумцима, који су „као неки стални осуђеници на смрт“ (ANDRIĆ 2011a: 29), већ и људима криминалних намера. Злочиначку парадигму уметника Гоја потврђује и тако што уметника дефинише као одметника - он је „изван закона“ - он отима:

„[... 그ијући од једног тамног света за други неки који нам је непознат, преносећи из ничега у нешто што не знамо шта је. Зато је уметник 'изван закона', одметник у вишем смислу речи, осуђен да надчовечанским и безизгледним напорима допуњује неки виши, невидљиви ред, реметећи овај нижи, видљиви, у ком би требало да живи целином свог бића“ (2011а: 26).

Овакво разматрање уметника уклапа се у Ничеово филозофско становиште (NIČE 2017: 15-16) и приближава књижевног јунака типу злочинца. Поред Сутона идола, о овој идеји Ниче је проговорио и у компилацији за живота необјављених есеја, а које је његова сестра, Елизабета Ниче, објавила годину дана након пишчеве смрти под називом Воља за моћ (der Wille zur Macht, 1901). Наиме, Ниче наводи да је цивилизацији познат само тип закржљалог злочинца, „кога је притиснуло проклетство и презирање друштва, који сумња у самог себе, а често умањује и клевета своје дело - дакле, неуспели тип злочинца“ (NIČE 2003: 299), али додаје и „да су сви велики људи били злочинци [...] да злочин иде уз величину“ (2003: 299). Уз овакво поимање злочина, он везује и појам слободе - „Слобода од предака, савести и дужности - то је опасност која прети сваком великом човеку. Али он је и хоће: он хоће велики циљ, па зато и средства за њ“ (2003: 299). Уколико уметника сврстамо у ред великих људи, тиме и ред злочинаца (2003: 299), неминовно је да преиспитамо његов циљ уметност и средство - стваране. Стварање по сваку цену.

Када је Фокнер (Faulkner) у једном од интервјуа говорио о уметницима, истакао је да је уметник „потпуно аморалан, толико да би опљачкао, позајмио, искамчио или пак украо од било кога и од свакога - само да би довршио своје дело. [...] Једина одговорност уметника јесте према његовом делу. Он може бити крајње немилостив [...]. Уколико писац 
мора да опљачка и своју мајку (не би ли довршио своје дело), неће оклевати“ (KAULI 1977: 123-124). Чак и у говору овог писца непремостив је мотив крађе и немилосрђа при стварању, те неминовно подсећа на оно што тврди Ниче (NIČE 2017: 105-106). Уметник мора да ствара, за то је предодређен, вођен напором који сам не бира, како Андрићев Гоја казује:

„Па ипак, тај напор који већини људи, и с правом, изгледа безуман и сујетан има нечег од великог нагонског упорства којим мрави подижу мравињак на прометном месту, где је унапред осуђен да буде разрован и прегажен“ (ANDRIĆ 2011a: 26).

То је готово нагонски порив, нешто унутрашње што управља бићем уметника (уп. ANDRIĆ 2011a: 26). Или пак нешто спољашње, у случају Тонија Крегера:

„Потпуно се предао сили [...] којој је, како је осећао, био позван да служи [...] сили духа и речи која смешећи се седи над престолом високо над несвесним и немим животом“ (MAN 2001: 28).

Отуд је проблематично колико се уопште концепт стварања може уклопити у темеље слободе. Тонио Крегер, поред тога што се предаје стваралачкој сили, стварање доживљава и као мучни проблем - „Нема проблема, нема га на свету, који би био мучнији од проблема уметничког стварања [...]“ (2001: 39). Стварање отуд јесте средство, али не средство воље уметника, већ његов једини израз, способност - једина сврха.

Иако се ослобађа друштвених конвенција, уметник стварањем не долази до слободе, већ само до другачијег облика сужањства - неконтролисаног, које је нагон (ANDRIĆ 2011а: 26), које је сила (MAN 2001: 28), али које уметника свеједно држи у оковима - будући да њоме не може управљати. Штавише, она управља юиме. Мановски речено - уметник мора служити (2001: 28), мора се покорити нечем што је више и јаче од њега самог, било оно спољашњег или унутрашњег устројства. Њега не покреће слободна воља, њиме нешто управља. Због тога уметник не сме да преза од начина на који ће стварати. Отуда је он спреман и да украде и опљачка не би ли стварао и задовољио одговорност према свом делу (KAULI 1977: 123-124). У питању је „неодољива и незајежљива тежња“ (2011a: 26) пред којом и Гоја стоји запитан:

„тежња да се из мрака непостојања или из тамнице коју представља ова повезаност свега са свиме у животу, да се из тог ништавила или из тих окова отима комадић по комадић живота и сна људског и да се уобличује и утврђује 'заувек', кртом кредом на пролазној хартији“ (2011a: 26). 
Злочин уметника јесте управо у стварању по сваку цену - цену крађе, одметништва, ремећења вишег и нижег поретка (2011a: 26). Према Ничеу, злочин спада у категорију „побуне против друштвеног поретка“ (2003: 300), а уметник јесте преступник и из разлога што не може да се усагласи са друштвеним приликама свог времена. Међутим, знајући да је и други свет - онај из кога краде - изгубио свој потенцијал и трансцедентне могућности - он ни у њему не налази ослонац.

Неприпадност ни једном ни другом свету доводи до раскола личности уметника, а његово понашање сугерише криминалистички етос. Такав склоп особина доминантан је и у тренутку када Гоја објашњава технику портретисања и истиче да је лице неопходно изнети „само самцито, као на губилишту“ (2011а: 32), да би потом уследило његово убиство, али и поновно рађање:

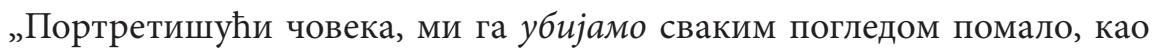
што биолози убијају животињицу коју препарирају, и кад га умртвимо потпуно, он оживи на нашој слици“ (2011а: 33).

Из Гојиног казивања произилази да уметник мора убити човека како би му подарио вечни живот кроз уметничко дело (2011a: 33). И у овом случају уметник јесте злочинац, он метафорички убија не би ли стварао, а једино се рђави сликари, како тврди Гоја, познају по томе што нису успели да изврше „тешки посао издвајања и ослобођења, 'убијања' и 'овековечења' личности“ (2011a: 33).

Пратећи злочиначки дискурс Гојиног монолога (2011a: 33), закључујемо да уметник мора починити преступ како би стварао, али и парадоксално - због таквог преступа он мора бити и кажњен у свету у ком ствара. Сличан став о уметнику заузима и Тонио Крегер док води разговор са Лизаветом Ивановном (MAN 2001: 38). Покушавајући да објасни шта је уметник, Тонио говори о „зло условљеном, до крајности 'сумњивом' дару“ (2001: 38). Лексички план изнова доноси везу - и Ман и Андрић указују на то да је парадигма уметника увек условљена сумњом и подозривошћу: Тонио Крегер такође има обрисе онога што Гоја дефинише као „сумњиво лице“ (2011a: 25) - када наратор говори о јужњачком темераменту Тонијеве мајке истиче како је сину било драго што њу не тишти „његов сумюив положај међу људима“ (2001: 11).

За овакво поимање уметника значајна је Крегерова прича о банкару са даром за писање новела (2001: 38-39). Крегер говори о човеку који је служио казну и једно време био лишен слободе (2001: 38-39). Таленат за писање је открио управо у заточеништву (2001: 38-39), што и потврђује нашу идеју о стварању које је условљено преступом. Крајње упориште за то је и изјава Тонија Крегера: „Отуда би се, са нешто дрско- 
сти, могао извести закључак да се човек мора одомаћити у некој врсти казненог завода да би постао песник“ (MAN 2001: 38). Тонио додаје и да не постоји беспрекорни банкар који ствара новеле (2001: 29), јер човек који ствара мора имати интегрисане злочиначке намере.

Такође, у поглављу у ком се Крегер враћа у свој родни крај, његов долазак у хотел заокупљује пажњу вратара:

„Испитљиво га посматраху и премераваху од главе до ципела; видело се да желе да му одреде друштвени положај, да га хијерархички и грађански негде уврсте, да нађу за њ место у своме поштовању, но да никако не могу да дођу до неког резултата [...]“ (2001: 51).

Немогућност вратара да одреде друштвену позицију Тонија Крегера условиће и суочење јунака са управником хотела и жандармом, који га поистовећују са варалицом „од непознатих родитеља, неизвесне надлежности, [кога] гони минхенска полиција због разноврсних превара и других преступа [...]“ (2001: 59). Изнова се успоставља веза између уметника и преступника самим тим што ће грађани показати немогућност њихове дистинкције (2001: 59). Међутим, оно што додатно усложњава злочиначко тумачење јесте да Тонио Крегер пристаје на овакву идентификацију: док је Гоја тврдио да је уметник „путник са лажним пасошем“ (ANDRIĆ 2011a: 25), Тонио заправо нема исправе (2001: 59), те постаје још сумњивији. Он може да разреши проблем свог идентитета тако што ће сугерисати да је син конзула Крегера (2001: 59), али то ипак не чини. Зоран Глушчевић у својој студији „Андрић и Гоја“ истиче како је уметник потпуно лишен идентитета, што је последица антагонизма у којем се налазе уметност и стварност (GLUŠČEVIĆ 1994: 122). Оваквом разматрању идентитета у нашој компаративној анализи доприноси већ споменуо удвајање перцепције јунака уметника - стапање личног и друштвеног. Код Тонија је случај нешто сложенији - његов идентитет нису у могућности да распознају други (уп. MAN 2001: 59) јер га и он сам проблематизује. Тониово амбивалентно порекло - строги отац и уметнички настројена мајка (2001: 11) - доприносе недоумици. Отуд Тонио размишља да жандармима каже ко је:

„Да ли да оконча ствар откривши се, да ли да објави господину Зехазе да он није варалица неизвесне надлежности, да није, по своме рођењу, Циганин у зеленим колима, но да је син Конзула Крегера, из породице Крегерових? Не, то му се није радило. А зар ови људи грађанског поретка нису донекле у праву? У извесном смислу се он слаже с нима“ (2001: 59).

Ипак, Тонио се не разоткрива, већ напротив, он даје за право жандарму и управнику то што га поистовећују са варалицом (2001: 59). 
Ћутањем пристаје на улогу коју су му доделили јер је сматра у већој мери опредељујућом за своје биће од свог стварног порекла (2001: 59). Наратор је то више пута и иницирао у тексту - када је током одрастања Тонио желео да га отац казни због недоличног понашања и изопаченог живота: „онда је бар у реду да ме озбиљно укоре и казне [...] Ми тек нисмо Цигани у зеленим колима, ми смо пристојан свет, кућа конзула Крегера“ (2001: 12). Међутим, у сцени са жандармом (2001: 59) - ћутање је знак да он пристојном свету не припада, иако чезне за њиме. Уметност, која већински обухвата Тонијево биће, није поштена и пристојна доктрина: „Поштен и здрав и пристојан човек уопште не пише, не глуми, не компонује (2001: 36). Он се отуд налази на другом крају ове друштвене поларности - на крају у ком су варалице, преступници, злочинци и криминални карактери.

Самим тим што је склоп уметникових особина дефинисан кроз параметре злочиначких намера, онда и он, у складу са критеријумима злочина и казне - мора бити осуђен и кажњен. Казна, сматра Ниче у Вољи за моћ, „изолује још више неголи злочин: коб иза преступа тако је постала страшна да је положај преступника безнадежан. После казне човек постаје непријатељ друштва“"(NIČE 2003: 301). Управо је и положај уметника безнадежан (уп. NIČE 2003: 301), док је он у непрестаној борби с друштвом.

Зато и Андрићев Гоја више пута спомиње како је уметник осуђен (ANDRIĆ 2011a: 26). По принципима правних наука, након злочина су нужне осуда и казна, а за разматрање књижевног јунака уметника оне поспешују амбивалентне могућности. Прва од њих јесте та да је уметник осуђен да ствара јер не припада свету у ком јесте; а друга је да је осуђен баш зато што ствара у свету у ком јесте. Амбивалентна осуда пак условљава недвосмислену казну - непрестано незадовољство уметника, његову неснађеност и окованост у свету у ком не постоји могућност остварења мимо уметности.

3. Умоболник и песник, од уобразиље саздани: ${ }^{4}$ болест као стваралачка енергија уметника

У оквиру тумачених остварења Мана и Андрића, неопходно је начинити још један истраживачки корак - перципирати уметничко стварање кроз постулате болести. Подробније - указати на који начин се стваралаштво Тонија Крегера и фиктивног Гоје може довести у везу са филозофским поставкама болести, као и на којој разини се оне могу

4 У питању је парафраза стиха из Шекспирове драме Сновиђеюе у ноћ иваюску: „[...] Умоболник, / Љубавник, песник - то су ти створења / Саздана сва од уобразиље“ (ŠEKSPIR 1963: 245). 
сагледати. Већ је утврђено да се већина наших филозофских гледишта заснива на Ничеовим тврдњама, па је отуд важно напоменути још једну, из Воље за моћ, која сугерише да уметника одликују изузетна стања: „то су стана која су интимно сродна болесним појавама и с њима срасла: тако да се чини немогућно бити уметник, а не бити болестан" (NIČЕ 2003: 325). Ово Ничеово запажање праћено је још мноштвом сличних, а која се тичу болесних и слабих људи:

„Болесни и слаби увек су опчињавали: они су интересантнији од здравих: лудак и светац - две најинтересантније врсте људи... у блиском сродству стоји гениј. Велики пустолови и злочинщи и сви људи, нарочито они најздравији, били су болесни у извесно доба свога живота: велике душевне покрете, страст за моћ, љубав, освету прате дубоки поремећаји“ (2003: 247).

Управо на размеђи злочинца и болесника Ниче смешта „прелазну врсту“ - уметника:

„apmucm, кога од злочинства на делу одваја слаба воља и страх од друштва: мада још не готов за лудницу, али са пипцима који радознало пипају по обема областима: ова специфично културна биљка, модерни артист, сликар, музичар, понајпре романсијер [...]“ (2003: 347).

Неизоставно је уочити тројну паралелу: злочинац - уметник (гениј, артист) - болесник (уп. NIČE 2003: 347). Док смо у пређашњем поглављу испитали злочиначки дискурс уметника, овде ће основни дискурс бити болест као стање које је неодвојиво од уметности, тиме и уметника. Већ се у свести Тонија Крегера уметнички порив дефинише као нездрав и болестан:

„Противно је свакоме смислу, ако уметник воли живот, да ипак тежи свим вештинама да га привуче на своју страну, да га задобије за утанчаности и меланхолије, за све болесно властеоство литературе. Царство уметности расте на земљи, а иарство здравља и безазлености опада $[\ldots]$ и кад неко радије разгледа књиге о коњима [...] не треба га хтети завести и примамити поезији!“ (MAN 2001: 44).

У оваквом обрнуто пропорционалном односу здравља и уметности евоцира се Манова идеја да је уметничко уједно и болесно, јер, како је у једном моменту овог рада већ и споменуто - „Поштен и здрав и пристојан човек уопште не пише, не глуми, не компонује“" (MAN 2001: 36). Уметничка делатност није резервисана за људе виспреног, здравог ума, за виталне и безбрижне. Напротив, она је плод искључиво меланхоличног расположења, умне растрзаности, неурастеније и раздражљивости. Уметника карактерише, како Крегер наводи, „артистички живчани си- 
стем“ (2001: 35) - посебан нервни склоп који није инхерентан здравом, обичном човеку.

Томас Ман је у својим есејима о уметничким генијима више пута спомињао феномен болести, те њен утицај на дух и тело човека. У есеју „Гете као репрезентат грађанског раздобља“ писац казује следеће:

„А како стоји са односом тога на виталност поносног човека према здрављу и према болести? Геније, ми то добро знамо, не може бити нормалан у простачком, у једноставном грађанском смислу, нити је оно што је природа највећма благословила икада у смислу филистарском природно, здраво, по правилу. Ту има у физичком животу увек много нежног, иритабилног, склоног кризи и болести, у психичком животу много чега што непријатно чуди просечног човека, нелагодно га дотиче, што је блиско психосоматском“ (MAN 1980: 53).

Није ли управо развојни пут Тонија Крегера испуњен овим превирањима? Његова раздражљивост више пута долази до изражаја, јављају се моменти у којима му се болно згрчи срце и буде скрхано пред налетима меланхолије, беде и уметничког понора (2001: 25). Чак се и код Гоје из Андрићевог књижевног света појављује неименована болест услед које се сликару јављају ноћне море и снови испуњени одјецима смрти mors који се очитује на зидовима - што траје све док, како јунак истиче, није „оздравио и вратио се у мирну власт разума“ (ANDRIĆ 2011a: 39).

Међутим, док је Ман о феномену болести проговарао кроз свој есејистички рад, Андрић је неколико запажања оставио у Знаковима поред nуma, његовом постхумно објављеном духовном дневнику. Андрић најпре безумну мисао доводи у контекст болести:

„Тешка, безумна мисао која дуго мучи и најпосле убија. Она је у мени као болест која се крије, али које сам свестан у сваком будном минуту. Она се претворила у трајно стаюе мога духа и, потискујући све остало, умртвила моју вољу и завладала свим радњама за које још не налазим снаге. [...] То је безуман напор који тражи стотину оваквих снага као што је моја. У мом случају, он је исто што и самоуништене“ (ANDRIĆ 1986: 39).

Безумна мисао (1986: 39) као еквивалент болести, као трајно стање духа и ума, са далекосежним деструктивним (али, према нашем мишљењу, и парадоксално - стваралачким) последицама - може се повезати са оним што аутор, док пише есеј „Гоја“ и приказује Гојин уметнички портрет скрхан болешћу, дефинише као болест ума (ANDRIĆ 2011b: 13):

„Каква је била Гојина болест? Шта јој је био узрок? Ништа се у овом чудном животу не зна поуздано, па ни то. На једном од фантастичних цртежа за време болести, Гоја исписује ситно, оловком: 'Кошмар 
који сам сањао, а да нисам никако могао да му се пробудим и да му се отмем'; а преко тога је написано крупним словима, мастилом и опет Гојином руком: Болест ума“ (2011b: 13).

Након ових података, Андрић евоцира и чињеницу да је Гоја постепено остао без слуха (ANDRIĆ 2011b: 18), те због ове болести постао додатно отуђен од света и друштвених дешавања. Овакво понашање не разликује се много од идеје коју аутор заступа у својим кратким записима из Знакова поред пута, у којима указује и на чудно понашање „једноставних, нагонских људи“ (ANDRIĆ 1986: 65) у периоду болести, када долази до осамљивања и отуђења:

„[...] они одједном остану сами са својом болешћу, као да намерно прекидају све везе. Кивни су на своју болест и на све око себе: обневидели, одједном не познају више оне који су им дотле били блиски и драги и не умеју да приме њихове савете и утехе, чак ни њихову помоћ. Болују као зверке“ (1986: 65).

Међутим, иако у Гојином случају такође долази до раскида свих веза са друштвом, аутор то сагледа као освајање извесног степена слободе:

„Сада, у болести, он је први пут остао сам и слободан да слика што хоће. У то време настала је његова велика збирка бакрописа [...] мешају се ноћна привиђења до болести раздражльвог духа са друштвеним карикатурама [...]. То је просто 'дневник болести' “(2011b: 14-15).

Кроз Гојин дневник болести Андрић настоји да проговори о слободи уметника, али у оквиру контекста јавно и приватно, будући да је Гоја најпре своје таленте усмеравао на испуњење друштвене сврхе (2011b: 10-11). Ради се заправо о ослобађању уметника у себи. Гојина друштвена личност сликала је за друге, а након болести, испољава се унутарњи, интимни моменат Гојиног бића, те се сликање преусмерава на себе - оно је само себи сврха:

„[...] по зидовима своје виле, у коју не улази нико, слика за себе поворке мрачних чудовишта и наказа [...]. Ни данас не може нико да нађе смисао тих језивих фресака; по њима се може наслућивати како је било у унутрашњости уметника који је раскинуо са богом, са светом и са самим собом“ (2011b: 18).

Довољно је сетити се канонског јунака уметника - Стивена Дедалуса из Џојсовог (Јоусе) Портрета уметника у младости (A Portrait of the Artist as a Young Man, 1916) - и узвика Non serviam! - којим јунак раскида са друштвом и догматским уверењима, те се потпуно окреће уметничком 
позиву:

„Нећу служити ономе у што више не верујем, звало се то мој дом, моја отаџбина, или моја црква, и покушаћу да се изразим у неком облику живота или уметности што слободније могу и што потпуније могу, служећи се у своју одбрану јединим оружјем које себи дозвољавам - ћутањем, изгнанством и превејаношћу“ (DŽOJS 2015: 242).

Уметност у том смислу постаје поље слободе. Ипак, да бисмо додатно протумачили и друге аспекте уметности, неопходно је да сагледамо још један исказ у Андрићевом постхумном делу:

„Наше меланхолије и наше болести, ситне и крупне, као и наши нездрави прохтеви и пороци - све су то само разни начини и покушаји да се човек некако преведе из живота у непостојане. Јер, смрт нас целог века дрма, вуче, удара и закреће час лево час десно, онако као што човек извлачи ексер из даске; укратко, чини све како би нас што пре извукла из живота“"(1986: 69).

Док Андрић сугерише како је болест само један од начина преласка у непостојање (ANDRIĆ 1986: 69), уметност уопште јесте много више од пуког преласка у смрт. Она је управо њено надвладавање - трајање. Осликавањем злослутних прилика изниклих из мрака и сенке Гоја пркоси смрти - надноси се над њу, превазилази је. То је један од момената парадоксалног сусрета аполонског и диониског порива - постизање склада и трајања путем приказа деструкције. Уколико бисмо Андрићеву запитаност „Музика је болест. Или ослобођење?“ (1986: 258) парафразирали у општу мисао о уметности - уметност би била болест $u$ ослобођење. Ослобођеюе стваралачког нагона посредством болести и његово транспоновање у уметничко дело (уп. ANDRIĆ 1986: 258). Уобличавање једног разорног импулса (болести) у неисцрпну и плодотворну енергију (уметност).

Међутим, у Гојином случају, освајањем уметничке слободе он је осуђен на другу врсту окова - то је сужањство унутрашњем пориву, већ поменутом у претходном поглављу. То је уједно и порив који је изашао на површину из интиме сликара и обликовао мрачна здања (уп. ANDRIĆ 2011b: 13). Андрић и казује да је болест условила „мрачну половину Гојина живота и рада, која нам је дала неједнака и бизарна, али дела од великог значаја“ (2011b: 13). У томе и јесте суштина Гојине свевремене патње - из мрака постојања ниче уметност, из нихилизма произилази катарзична снага уметничког дела.

Како Адријен Сузман (Sussman) наводи, један од стереотипа културе јесте тип „намученог уметника“, као и контрадикција да он ствара изузетна дела упркос (или, како ауторка наводи у парентези, управо због) своје болести (SUZMAN 2007: 21). Велики број научних студија говори о 
вези између менталних болести и креативности, те ова ауторка и издваја неке од њих, ${ }^{5}$ тумачећи са неуролошког аспекта овакве могућности (2007: 21-22). Међутим, како ауторка и сама примећује, претпоставке датирају још од античких разматрања инспирације и уметничког стварања - већ је Платон у Федру рекао да је „лудило“ продукт рајске моћи, оно долази од божје промисли, док су трезвене ствари чисто људске (2007: 21). У свом истраживању Сузман наводи и психијатријску студију новијег датума, у којој доктор Лудвиг испитује везу између културолошких утицаја и менталних болести и доказаује да су професије које се тичу уметничког стваралаштва (песници, писци, визуелни уметници, музичари, глумци) склоније менталним болестима од особа других занимања (2007: 22). Сва ова тумачења потврђују овде анализирану везу између болести и уметности, и у научном, али и превасходно - у књижевном смислу.

Идеја патње за коју је уметник нераскидиво повезан устоличена је и у Мановом есеју о Вагнеру „Патња и величина Рихарда Вагнера“ (Leiden und Größe Richard Wagners, 1933), где нобеловац наводи Вагнеров стих: „У ствари, осећаш се бедно, али ипак се осећаш“ (MAN 2001: 192) и коментарише га:

„То је један узвик збуњеног и десператног самоисмевања из Вагнерових писама. И он није пропустио да успостави узрочну везу између своје патње и свог уметничког бића, да уметност и болест протумачи као једно исто искушење“" (MAN 1980: 192).

Идентичну улогу Ман даје и свом фиктивном уметнику - док Тонио Крегер посматра плес плаве Инге и Ханса Ханзена, усамљен, из тамног прикрајка, једна мисао провејава:

„Да, сасвим је тако као тада, и он је срећан као тада. Јер юеггво срие живи. А чега је било за све то време у којем је постао оно што је сада? - Укочености; пустоши; теда; и духа! И уметности!“" (MAN 2001: 81).

Крегерово уметништво и инспирација утемељени су управо на болу и неприпадности модроокима, којима вечито тежи, за којима чезне, које помало и презире (2001: 43-44). Међутим, његова уметност резултат је управо комике и беде (2001: 28) тога осећаја. Без бола, без његовог крхког срца - не би било ни остварења која је за собом оставио. Због тога је и у моменту истинске патње присутна срећа. Међутим, срећа је за Тонија Крегера, као и уметника уопште, врло проблематична идеја.

Наиме, може ли уметник бити срећан? Уколико се његово стварање заснива на болним искуствима и растрзаном, неурастеничном умном склопу, колико је срећа могућа? „Он је срећан као тада“, наводи при-

5 За више информација погледати SUZMAN 2007: 21-22. 
поведач у тренутку када Тонио посматра плес (2001: 81). Међутим, срећа није трајно стање за уметника. Она то не може бити. Крегер то и сам потврђује својим исказима: „Тако леп и ведар је само онај који не чита Имензе и никад не покушава да сам тако што напише; и то је оно што је тужно!“ (2001: 24) - уколико ведрину у овом контексту заменимо срећом, можемо закључити да је неминовно да онај који је осуђен на проклетство уметности - не може бити обележен трајним оптимизмом.

Међутим, залазећи у даљу дискусију, неопходно је запитати се због чега је то тако? Чиме је уметнику онемогућена непрекидна срећа у свету, иако се у њему друштвено не сналази?

Одговор је у ономе што Манов јунак дефинише као „случај Хамлета Данца“ (2001: 41) - у сазнағы. Човек је позван на сазнағе, али није рођен за њега, те не може поднети тежину терета који ломи сваку могућност среће и безазленог уживања. Сазнане омогућава трансформацију човека у уметника. За сазнағе су кључне Ничеове идеје, чији утицај признаје и са̂м аутор ове новеле у свом есеју „Фројд и будућност“:

„И ја никада нећу заборавити како је доживљај Ничеовог психолошког страдања оснажио и продубио моје склоности. Реч 'гађење од сазнања стоји у 'Тонију Крегеру'. Она је добрано ничеовска кова, а њена младићка сета указује на хамлетовске црте у Ничеовој природи, у којој се одражавала моја [...]“ (1980: 287).

У истом есеју, свега неколико мисли касније, Томас Ман указује на то да је „болест као средство сазнаға“ (1980: 288), што је такође утицај Ничеа „који је добро знао шта дугује својој болести и који као да на свакој страници учи да нема никаквог дубљег знања без искуства болести“ (1980: 288). У томе је и једначина наше кључне тезе - долазак до сазнања условљен је неком врстом болести, изузетног нервног склопа и мисаоне активности, те је болест инхерентна за уметништво. Без сазнања - нема уметности. Без болести - нема сазнања. Уз сазнање и уметништво - срећа није могућа.

„Бити видовит још и кроз сузни вео осећана, сазнавати, памтити, посматрати, и са осмехом све то морати стављати на страну [...] - то је инфамно, Лизавета, то је ниско, то узбуюује... али шта вреди бунити ce?" (MAN 2001: 41).

Уметник се не може отргнути од свог неурастеничног мисаоног склопа, самим тим ни сазнања, а резултат оваквих деструктивних инсинуација јесте опредељеност за уметност, за стварање. Иако у томе не налазе срећу, уметници једино кроз стваралачки модус могу живети и, што је још важније - трајати. 


\section{4. Закључак}

У раду је представљен непрестани сукоб између света уметника и грађанства, те маргинална позиција коју уметник у друштвеним околностима заузима. Уметника као јунака периферије представили смо на трагу Ничеових теоријских упоришта и то са аспекта две маргинализоване групе - злочинаца и болесника. Сагледајући уметника кроз криминалистички етос, закључили смо да уметник мора починити преступ не би ли стварао, што условљава осуду и казну, његову друштвену отуђеност, незадовољство и немогућност егзистенције ван уметности. С друге стране, дефинишући артистички порив кроз неурастенични мисаони склоп Гоје и Крегера, тумачили смо уметност као последицу патолошког стања књижевних јунака и као једини облик њихове самоекспресије. Оба полазишта нашег тумачења темеље се на деструктивним импулсима јунака, а закључак је посве опречан - кроз деструктивну енергију ослобађа се она стваралачка, која уметнику омогућава да ствара, а његовом делу - да траје.

\section{Цитирана литература}

ANDRIĆ 1986: АНДРИЋ, Иво. Знакови поред пута, Сарајево: Свјетлост; Београд: Просвета; Загреб: Младост; Љубљана: Државна заложба Словеније; Скопје: Мисла; Титоград: Побједа, 1986.

ANDRIĆ 2011a: АНДРИЋ, Иво, „Разговор с Гојом“, Гоја. Београд: Службени гласник, стр. 22-41, 2011.

ANDRIĆ 2011b: АНДРИЋ, Иво. „Гоја“, Гоја. Београд: Службени гласник, стр. 8-19, 2011.

ĐURČINOV 1981: ЂУРЧИНОВ, Милан, „Маскирани човек у сумраку“, Дело Иве Андрића у контексту европске књижевности и културе, Београд: Задужбина Иве Андрића, стр. 103-109, 1981.

GLUŠČEVIĆ 1994: ГЛУШЧЕВИЋ, Зоран, „Андрић и Гоја (Записи о Гоји и Разговор са Гојом)“, у: Милослав Шутић, ур., Андрић у светлу естетике, Нови Сад: Светови, Београд: Институт за књижевност и уметност, Задужбина Иве Андрића, стр. 115-129.

MAN 1980: МАН, Томас. Есеји. прев. Томислав Бекић, Нови Сад: Матица српска, 1980.

MAN 2001: МАН, Томас, „Тонио Крегер“. Изабрана дела. прев. Аница Савић Ребац, Београд: Дерета, стр. 5-86, 2001.

NIČE 2003: НИЧЕ, Фридрих. Воља за моћ. прев. др Душан Стојановић, Београд: Дерета, 2003.

NIČE 2017: НИЧЕ, Фридрих. Сутон идола или Како филозофирати чекићем. прев. Јовица Аћин, Београд: Астролаб, 2017.

DŽOJS 2015: ЏОJC, Џејмс. Портрет уметника у младости. прев. Петар Ћурчија, Београд: ЛОМ, 2015. 
ŠEKSPIR 1963: ШЕКСПИР, Виљем, Забуне - Много буке ни око чега - Сновиђене y ноћ иваюску, прев. Велимир Живојиновић, Београд: Култура, 1963.

KAULI 1977: COWLEY, Malcom. Writers at work, Penguin Books Ltd: Middlesex, England, 1977.

SAVIĆ REBAC 2015: САВИТ РЕБАЦ, Аница, Дух хеленства, Београд: Службени гласник, 2015.

SIMIĆ 2017: СИМИЋ, Анка, „Андрићева легенда о уметнику: Разговор с Гојом“, Наслеђе: Часопис за кюижевност, језик, уметност и културу, Година XIV, Број 36, Крагујевац: Филолошко-уметнички факултет, 2017, стр. 61-68.

STOJANOVIĆ 1997: СТОЈАНОВИЋ, Драган, Парадоксални класик Томас Ман, Београд: Завод за уџбенике и наставна средства, 1997.

SUZMAN 2007: SUSSMAN, Adrienne. „Mental Illness and Creativity: A Neurological View of the 'Tortured Artist'", Stanford Journal of Neuroscience, Volume I, Issue 1, pages $21-24,2007$.

TARTALJA 1979: TAPTAљA, Иво, Приповедачева естетика: Прилог познавағу Андрићеве поетике, Београд: Нолит, 1979.

Sara Arva

\section{ART - CRIME OR ILLNESS: GOYA AND KRÖGER IN A COMPARATIVE STUDY}

The aim of this paper was to show an artist as a literature character in Andric's essays „Conversation with Goya" and „Goya“ and in Mann's novella „Tonio Kröger“. Comparison was based on Nietzsche's philosophical thoughts, as figure of artist was shown as a marginalized individual who cannot fit in modern society. Considering his problematic identity, this research focused on two significant aspects of artist and his creation - analyzing him as a criminal, a person who must make an offense in order to create; and as a pathological being, who resolves his inner conflicts by making art. In conclusion, both cases show the same outcome: art as an expression and the only way of artist's problematic existence.

Keywords: Andric, Mann, Nietzsche, art, artist, society, crime, illness 